\title{
Analysis on the Countermeasures of Higher Education Helping Targeted Poverty Alleviation in the Post Poverty Alleviation Era
}

\author{
Senyu Yang \\ Guangxi Normal University, Guilin 541004, P. R. China
}

\begin{abstract}
In the decisive year of the battle against poverty in, the Chinese people, under the leadership of the Communist Party of China, adhered to the "last mile of poverty alleviation" and fought the "last battle of poverty alleviation". China has completed the task of poverty alleviation in the new era as scheduled. Under the current standard, the poverty alleviation rate of the rural poor has reached 100\%, eliminating absolute poverty and regional overall poverty. The focus of China's poverty alleviation work will also change from eliminating the absolute poor to alleviating the living conditions of the relatively poor.2021 is the first year of the post poverty alleviation era, and clarifying the work focus of the "post poverty alleviation era" is the top priority. Education is the internal driving force to improve the level of national economy and the comprehensive quality of the people. In particular, higher education has its unique role and significance in solving the employment of the poor. Combined with the current situation of targeted poverty alleviation by higher education, this paper will analyze the relevant countermeasures of targeted poverty alleviation by higher education.
\end{abstract}

Keywords: Targeted poverty alleviation in Higher Education in the post poverty alleviation Era.

\section{Concept Elaboration}

Targeted poverty alleviation is aimed at extensive poverty alleviation. It refers to a poverty control method that uses scientific and effective procedures to accurately identify, assist and manage the poverty alleviation objects in different poverty-stricken regional environments and the conditions of poor farmers. Targeted poverty alleviation includes: first, accurate identification, which is the premise of targeted poverty alleviation. Identify poor residents through effective and compliant procedures; Second, precise assistance, which is the key to targeted poverty alleviation. After the poor residents are identified, the responsible person and assistance measures shall be determined according to the poverty situation of the poverty alleviation object to ensure the assistance effect; Third, accurate management, poverty alleviation should not only be accurate, but also have safeguard measures to ensure the effectiveness of poverty alleviation, which is the guarantee of targeted poverty alleviation.

\section{Current Situation and Dilemma of Efficient and Targeted Poverty Alleviation}

2.1 The Integrity of Education Funds is Insufficient, the Poverty Alleviation Funds are Insufficient, and the Source of Funds is Relatively Single

Since the 18th CPC National Congress, the state has proposed that the financial education fund should not be less than $4 \%$. Although the proportion of education investment in China has increased slowly in recent years, there is still a widening gap compared with developed countries such as the United States and Japan. At present, the policies adopted by the Chinese government in promoting targeted poverty alleviation in higher education are mainly financial assistance, that is, providing educational facilities and resources, providing financial assistance to poor students, including giving awards, loans, subsidies and exemptions to poor students, or providing work study opportunities. Although there are many forms of financial aid for poor students, it cannot completely reduce the economic pressure and life pressure of poor college students, and even some poor students have the economic pressure caused by insufficient tuition fees. In addition, there are great differences in social resources in different regions, which makes the targeted poverty alleviation of higher education face many difficulties. In terms of scholarships, the amount of scholarships set by the state is low, which cannot ensure that poor students pay tuition and living expenses within one semester. In terms of student loans, the loan policy issued by the state is to delay the payment of tuition fees. However, due to the slow progress of bank loans, strict audit and small amount of loans, it is difficult for students to apply for student loans. Therefore, it is necessary to increase the investment of poverty alleviation funds for poor college students. In addition, the main sources of poverty alleviation funds in Colleges and universities are national and local governments, and the way to obtain poverty alleviation funds is relatively single.

2.2 The Development of Colleges and Universities in the Central and Western Regions is Uneven, and the Accuracy of the Student Assistance System is Lack

Poverty alleviation through education is a comprehensive project with strong systematicness and periodicity, especially the targeted poverty alleviation through higher education. Therefore, colleges and universities should formulate a long-term and perfect poverty alleviation system in the process of implementing education targeted poverty alleviation [1]. However, most colleges and universities lack such a poverty alleviation system, which is mainly reflected in the imperfect identification mechanism of poverty alleviation objects in higher education. In many colleges and universities, it is difficult to identify the target of targeted poverty alleviation, and the identification procedure is relatively simple, resulting in the phenomenon of forging the identity of poor students. At the same time, in the specific identification 
process, there is still a lack of unified quantitative methods to define the economically poor college students, which makes it difficult for colleges and universities to accurately identify the funded objects [2]. Targeted poverty alleviation in higher education itself is a huge project. Under the condition of certain capital investment, it also needs to have a perfect organization and guarantee mechanism. It is mainly reflected in the fact that the distribution of the average amount of poor students is not clear, and the work after the subsidy is not planned and guaranteed.

\subsection{The Efficient Assistance Mechanism is Lack of Long-term Effectiveness, and the Training of Poor Students is Lack of Pertinence}

For targeted poverty alleviation in higher education, Chinese scholars have put forward measures in three aspects: targeted enrollment, targeted funding and targeted employment. However, in specific practice, it is found that the mechanism operation of the three links lacks coherence [3]. For example, at the level of precision employment, because the specialty setting and curriculum system of colleges and universities are not perfect enough, they failed to further strengthen the connection between poor students and the employment market and ensure the employment development of poor college students. In addition, the education and teaching method for poor students in Colleges and universities is still the traditional assistance system, which lacks enough attention and targeted training. In terms of teaching resources, there is a lack of majors, courses and training programs to promote the development of poor college students from a low starting point. Many colleges and universities have neither formed advantageous and characteristic majors and unique curriculum resources suitable for the development of poor college students, nor built new majors or opened new courses. In terms of teacher allocation, the number of poverty alleviation teachers in Colleges and universities is seriously insufficient. Poverty alleviation teachers do not grasp the characteristics of special groups such as poor students in Colleges and universities, and their professional level is not high. They cannot fully understand the overall situation of the education level of poor students, which is not conducive to the smooth lifting out of poverty of poor college students. In terms of skills training, there are few innovation and entrepreneurship practical education and employment skills training for poor college students, and the coverage is not wide enough.

\section{Analysis on the Countermeasures of Poverty Alleviation in Colleges and Universities}

\subsection{Ensure the Superiority of the Education Fund System and Expand the Access to Funds}

Adequate funding is an important guarantee for targeted poverty alleviation in Higher Education in ethnic minority areas. In addition to increasing the investment in targeted poverty alleviation, colleges and universities should also raise funds through various ways to ensure the source of funds. At the same time, formulate the fund use plan, make full use of the existing funds and improve the use efficiency of funds. First, colleges and universities should establish a special poverty alleviation fund to ensure sufficient poverty alleviation funds and form a long-term, stable and effective investment mechanism for poverty alleviation through education. At the same time, the existing funds shall be reasonably planned and supervised, and the blind use of a large amount of funds shall be refused. In addition, when receiving the targeted poverty alleviation funds invested by the government, local colleges and universities should actively sign agreements with them, accurately locate the objectives of education targeted poverty alleviation projects, conduct real-time tracking and investigation on the use of funds, actively require professionals to evaluate the final results, and supervise and manage the use of poverty alleviation funds. Second, adopt diversified financing methods for poverty alleviation through education, encourage enterprises, industry associations, non-governmental organizations and third-party institutions to participate in poverty alleviation through education, and promote diversified and coordinated targeted poverty alleviation through higher education. Therefore, it is necessary to further improve the system and mechanism to promote the transformation of targeted poverty alleviation in Higher Education from the government-oriented model to the multi collaborative model of government, administration, enterprises and schools. Government departments should strengthen overall planning, endow industry organizations with more functions, guide the resources and strength of industry organizations, and fully participate in the targeted poverty alleviation of regional higher education.

\subsection{Take Measures According to Local Conditions, Give Play to Regional Advantages and Strengthen the Practice of Poverty Alleviation through Education}

Targeted poverty alleviation through higher education needs to meet the needs of the job market and realize the circulation of human capital. Therefore, colleges and universities should establish an education system suitable for poor college students, so that poor college students can realize employment as soon as possible during or after receiving higher education[4].First of all, establish and improve the innovation and entrepreneurship education system integrating classroom teaching, autonomous learning, comprehensive practice, guidance and assistance, cultural guidance and so on, which is suitable for the needs of development, optimize the specialty setting and curriculum system, and pay attention to the cultivation of poor college students; innovative spirit, innovative consciousness and innovative and entrepreneurial ability. First, we should strengthen the implementation of the practical teaching links of poor college students, formulate practical teaching plans, practical teaching standards and practical achievement assessment methods, innovate the experimental training system and content, carry out substantive training, and improve the practical teaching links. Second, we should strengthen the guarantee of practical teaching for poor college students, strengthen the construction of experimental teaching conditions, strengthen the sharing of laboratories between colleges and enterprises, and consolidate and develop all kinds of practice and training bases. Third, improve the innovation and entrepreneurship education system of local colleges and universities, promote the organic integration of professional education and innovation and entrepreneurship education, set up basic compulsory courses and a series of general elective courses for innovation and 
entrepreneurship, and actively cooperate with other industries to develop entrepreneurship education and training courses, so as to fundamentally improve the employability of poor college students.

Secondly, colleges and universities should carry out the construction of industry university research integration platform, strengthen school enterprise cooperation, actively build a practical education base with local enterprises in different industries, and give full play to the synergy of industry university research in talent training. In the actual teaching process, various education and teaching modes such as modern apprenticeship training is implemented to enable poor college students to obtain as many skills and career opportunities as possible. Finally, strengthen poverty alleviation cooperation with social forces and economic subjects [5]. Pay attention to the role of enterprises as the main body of higher education, let enterprises bring jobs to local universities to carry out poverty alleviation activities, carry out point-to-point training according to the needs of the industry, and form a poverty alleviation model of higher education with resource sharing and win-win cooperation. At the same time, coordinate and guide enterprises outside the region to participate in education and teaching, set up special classes of different types, donate teaching instruments and equipment, and work together to cultivate high-quality talents.

\subsection{Establish an Education Poverty Alleviation Account and Improve the Targeted Poverty Alleviation Mechanism}

In practice, targeted poverty alleviation in higher education cannot effectively achieve poverty alleviation by relying on short-term training, and even crash classes cannot effectively improve the literacy of poor college students. Therefore, when formulating the targeted poverty alleviation plan of higher education, we must first understand the main reasons for the poverty problems of poor college students, formulate the poverty alleviation plan according to the real needs of poor college students, build a long-term and adaptive targeted poverty alleviation mechanism of higher education, and strive to fundamentally eliminate the poverty problem. First of all, we must fully respect the law of higher education development and set up different types of detailed accounts for poor college students. First, we should follow the periodicity of higher education development and establish a hierarchical account for targeted poverty alleviation in higher education. Colleges and universities should put forward the corresponding stages of education targeted poverty alleviation according to each level of their own teaching system, clarify the time node, set up task objectives, compare teaching tasks and objectives, and establish a hierarchical account for the education of poor college students in the education poverty alleviation plan. Second, follow the characteristics of the types of higher education and establish a ledger for targeted poverty alleviation in higher education. Secondly, use the big data information management system to accurately locate the objects of poverty. To improve the efficiency of targeted poverty alleviation in higher education, the most important thing is to accurately grasp the target of poverty. We should quantify the poor students through data to effectively avoid the disadvantages of the identification of poor students caused by the traditional survey method and poverty proof method.
Therefore, colleges and universities should develop big data information management system according to their needs, and make use of the advantages of data analysis to collect all kinds of information of poor college students in an all-round way. This information mainly includes the consumption of poor college students during school, their expenditure on learning and their access to financial assistance. It can dynamically monitor poor college students and comprehensively understand poor college students. At the same time, with the help of big data information management platform, the actual situation of poor college students is transformed into quantitative data. Through descriptive analysis of the data, the difficulty degree of poor college students is ranked, so as to determine the school; assistance to poor college students and maximize the assistance effect [6]. Finally, establish and improve the tracking and feedback mechanism for poor college students, effectively use the evaluation results, carry out dynamic subsidy management for poor college students, and ensure the accurate early warning of poor college students. In the process of implementing targeted poverty alleviation in higher education, it is necessary to timely monitor the dynamic changes of poor college students, reduce the deviation of assistance, and improve the safety and timeliness of the identification data collection and updating process of poor college students. Therefore, in the process of helping poor college students, colleges and universities should establish and improve the feedback and notification mechanism for poor college students, update and feedback the poverty status of poor college students in real time through comprehensive analysis and management of students \& apos; consumption behavior, family economic situation and academic situation, start the early warning mode for poor college students, and pay attention to the situation of poor college students at any time, For the college students whose situation has deteriorated due to emergencies or other reasons in the feedback results, targeted measures should be taken in time to improve the efficiency of college funding poor students and promote poor college students to get out of poverty smoothly. At the same time, for poor college students whose situation has improved in the feedback results, they can be required to take the initiative to withdraw from the subsidy, so as to timely adjust the qualification and grade of poor college students.

\section{References}

[1] Dai Ruihua, Yu Xuan. Targeted poverty alleviation through education: Dilemma and governance path[J]. Research on education development, 2017, 37(07): 9-15+30.

[2] Li Xingzhou. Fairness and justice: the value pursuit of poverty alleviation through education[J]. Educational research, 2017, 38(03): 31-37.

[3] Wang Jiayi, Feng Qingyun, Zhang Jin. Education and targeted poverty alleviation[J]. Educational research, 2016, 37(07): 12-21.

[4] Liu Junhao, Xu Fenghua. Poverty alleviation through education: from "supporting the poor through education" to "poverty alleviation through education" [J]. Journal of education of Renmin University of China, 2016 (02): 44-53. 
[5] Zhu Aiguo, Li Ning. Research on targeted poverty alleviation strategy of Vocational Education[J]. Vocational Education Forum, 2016 (01): 16-20.

[6] He Pijie. Thoughts on targeted poverty alleviation in Vocational Education[J]. Education and occupation, 2015 (30): 5-7. 